\title{
Естетична комунікаційна функція і «матеріальне» значення слова в фольклорному тексті
}

\author{
Л. М. Копаниця \\ Київський національний університет імені Тараса Шевченка, м. Київ, Україна \\ Corresponding author. E-mail: lubovkopanytsya12@gmail.com
}

Paper received 22.01.20; Accepted for publication 05.02.20.

\section{https://doi.org/10.31174/SEND-Ph2020-217VIII65-06}

Анотація. У студії запропоновано інтерпретацію естетичної комунікаційної функції еротичного підтексту фольклорного твору як внутрішній зміст слова, культурний код у його метафоричних перетвореннях, окремого роду «мову» людського спілкування, що загалом сприяє формуванню пісенної поетики. Сформульовано критерії та методологічні засади вивчення символіки ліричних пісень.

Ключові слова: лірична пісня, еротичний підтекст, символ, поетична мова, комунікачія.

Вступ та короткий огляд тематичних публікацій. У своїй рецензії 1900 року на публікацію еротичної поезії українським археологом, етнографом й антропологом Федором Вовком фольклорист Володимир Гнатюк підкреслював не тільки важливість для науки цього видання, а й те, що «багато народних звичаїв можна також лише звідси пояснити» [6, с. 32]. Дійсно, сучасні дослідження фольклору довели, що рівнозначне прочитання творів пов'язано не 3 переоцінкою чи іншим ставленням до народної культури, тем, мотивів, образів, а з удосконаленням методів дослідження та зі спробою реконструкції минувщини [1]. Вивчення семантичного контексту конкретного фольклорного тексту уже само по собі $є$ реконструкцією давньої духовної культури. Це особливо цінно для дослідження жанрів і творів усної словесності пізніших епох 3 метою відновлення давнього світобачення та способів його відтворення в слові як основи національної культури, «яка зводиться до комплексу міфологічних уявлень про будову світу, властивих цьому соціуму, <...> ніде експліцитно не виражена, а реконструюється лише в сумі всіх своїх фольклорноетнографічних конкретизацій» [2, с. 101].

Якщо з суми мотивів народних пісень про кохання виділити провідні, що дозволяє характеризувати їх як жанровий різновид ліричних, то вони, бачимо, відтворюють не будь-які реально-побутові та соціальні ситуації життя, а в окремих елементах, аломотивах, образах картини світу транслюють ті основні модуси людської культури, що в поетичному тексті детермінують найважливіші функції народної культури: світоглядну, когнітивну, комунікативну, психотерапевтичну. Водночас весь континуум функцій та функціональних атрибутів, пов'язаний з пісенними мотивами й образами, взаємодіє 3 кількома кодифікованими сферами людського буття, однією з яких є царина сексуального життя. Отже, існування еротичного шару в традиційній культурі зобов'язує дослідників до його всебічного аналізу. Безперечно, така «неакадемічна» проблематика, як еротика, зустрічає на своєму шляху ряд труднощів. Ці труднощі пов'язані 3 тим, що донедавна більшість 3 того, що стосується цієі ділянки народної творчості, не завжди виділялось, а пропускалось і у виданнях творів усної народної культури, і при їх вивченні, хоча записи «неподобних» пісень можна зустріти в першого-ліпшого етнографа, котрий бодай трохи цікавився весільними звичаями.

Метою студії $є$ інтерпретація естетичної комунікаційної функції еротичного підтексту усної поезії як «мо- ви» людського спілкування та розгляд критеріїв і методологічних засад вивчення символіки ліричних пісень.

Матеріали і методи. Об'єктом дослідження є народні пісні про кохання. Предметом дослідження - теоретичні проблеми вивчення поетики жанру і принципів аналізу пісенного тексту.

Результати дослідження. Питання історичного розвитку необрядової лірики еротичного змісту потребує окремої відповіді. Втім, не важко помітити, що аналіз поетичних детермінант (сюжету, мотиву, образів або деталей предметної зображальності, художніх засобів) пісень про кохання відкриває нам умови, які лежать в основі розуміння їх як фольклорного тексту. Перша еволюція еротичної тематики, яка демонструє кілька етапів у іiї розвитку: архаїчний і пізній. А друга - естетична комунікаційна функція еротичного підтексту цих пісень, яка служить формуванню пісенної поетики як окремого роду «мови» людського спілкування, і $є$ інтегруючим началом. Але тут важливо підкреслити: до сприйняття реципієнтом змісту пісенного твору з еротичним підтекстом долучаються як образи, метафори разом 3 їхнім емоційним контекстом, які випливають 3 неусвідомлюваного, так і свідомий рівень їх розуміння, іншими словами, спільна культурна пам'ять.

Втім, мабуть, справедливим буде твердження, що еротичний підтекст в піснях кохання - це передовсім його форма та іiі перетворення: гра емоцій, надсильні символічні образи, це віддзеркалення безкрайнього світу людської душі й відтворення переживань нового інтимного досвіду. Тут характерними рисами «еротичної мови» пісень $\epsilon$ присутність архаїчних сюжетів, присвячених «війні», «бійці», «змаганню», мотивів, де змальовується бажання та знання героїні, з якого боку підійти до любовної гри, мотив «пожирання» або «знищення», які однаково зустрічаються як у піснях, що розкривають смисл сексуальної ситуації, так і в піснях, які описують любовні стосунки. Адже сексуальність у первісному суспільстві - це «феномен культури» і в цьому значенні вона не має ніякого відношення до дітородіння. 3 одного боку, секс сприймається міфопоетичною свідомістю як діяльність, що має характер медіації [4, с. 201-204] і співвідноситься з космогонічним процесом [7, с. 12]. 3 другого - сексуальність служить для досягнення поетичного екстазу, що, за Фройдом, є найдавнішою й найважливішою формою людського спілкування, є своєрідною «мовою» комунікації й інтегруючим началом [8]. Фактично поетична думка у піснях кохання переймаєть- 
ся не так абстрактним питанням «почуттєвість», а намагається мовою символів сексуальної активності гармонізувати світ на рівні свідомості, тому, природно, і цілком конкретно - проблемою перемоги, виграшу, гри. Це не означає, що гра неодмінно переростає в культуру, однак еротика в ліричному творі - це неодмінно гра емоцій, фантастичні образи, розкриття порухів людської душі, переживання нового інтимного досвіду. Нарешті, «мовний» рівень фольклорного твору передбачає пошук таких моментів, коли сама адекватність мови як посередника комунікації ставиться під сумнів. Це загалом можна було б охарактеризувати як культуру слова - його здатність так гнучко й різноманітно розвиватися, що воно аж ніяк не зводиться до свого прямого, «матеріального» значення, оскільки межа між матеріальною й духовною культурою в еротичному аспекті надто відносна. Це стається, коли пісні про кохання, подібно кожному жанру традиційної культури, використовують узвичаєні символи, метафори, евфемізми, пов'язані з любовношлюбним i еротичним змістом, i трансформують їх у залежності до своєї лірично-емоційної жанрової природи.

Так, інтимне життя в пісенних творах передається за допомогою надзвичайно багатої символіки. Символіка любовного почуття, любовної жаги, стосунків закоханих у ліричних піснях різноманітна й витончена, поетична й таємнича, однак значення багатьох мотивів та художніх образів традиційно пов'язане з ідеєю прокреації та подружнього щастя. Прагнення висловити, змалювати інтимні почуття або звичні ситуації у стосунках закоханих любовні пісні метафоризують, надаючи специфічного й виразного змісту цілком буденним і прозаїчним діям. А еротичними символами в поетичному контексті міг бути увесь навколишній світ: дерева, квіти, дикі звірі та домашні тварини, побут і предмети матеріальної культури, абстрактні поняття. За модель тут, знову ж таки, узято прадавню генетичну й типологічну спорідненість таких фольклорних мотивів і метафор, як «оранка й засівання ниви» у розумінні «любитися» $\mathrm{i}$ «одружуватися», «їсти», «пити» у значенні «любити», які в піснях кохання загалом несуть обсценний зміст, процеси «ткання», «варіння», «розривання», які набирають у пісенному тексті прокреативного значення, - і що в міркуваннях О. Потебні, М. Сумцова, М.Грушевського означає їхню семантичну тотожність, але завжди морфологічну неоднаковість.

Можна сказати: те, що народна культура традиційно обирала для опису картини світу (оранка, городні роботи та, звичайно, дім - цей давній символ людини в усіх народів), пісенний фольклор найчастіше практикує в еротичних символах. Цей висновок треба розуміти, спершу, як свідчення стабільності та мобільності усної культури. Або інакше - як художній образ, художній засіб, котрий підтримує в пісенному тексті функціональність сприйняття сталих понять та образно-символічних виразів, які виникали як узагальнення типових для свого часу життєвих явищ та уявлень про світ, як концепцію дійсності у свідомості носіїв культури, бо «кожна реальна потреба має своє осмислення» (О. Фрейденберг). Тому в «сороміцьких» піснях, як і в більшості текстів інших фольклорних жанрів, у позначенні еротичних мотивів, співвідношенні чоловічого/жіночого переважають радше символічні аналоги (предмети природи - земля, зер- но, кунка, галка, кінь, бугай, тур, віл чи предмети матеріальної культури - борона, макогон, голка, віник, веретено, ступа, каша, рукавиця, горщик, ринка, бандурка), рослинні символи жіночого первня (м'ята, калина, рожа, квіточка), статеві стосунки з боку жінки співвідносяться з виключно жіночими справами (товкти зерно в ступі, мішати кашу колотівкою, плести решето, прясти вовну, иити, замітати сміття (пір'я, черепки) віником, бити горщики), ніж пряма номінація сексуальної практики. Звідси в піснях інакомова, обігравання прямого значення, використання евфемізмів, криптограм. Так, у пісні «Ковалю-коваленьку» 3 умислом та однозначно змальовується сексуальна сцена, але сама демонстративна простота цього діяння підказує «відчитати» зміст пісні по-різному. А саме: як зображення тілесного у прихованих, утаємничених формах. 3 іншого боку, ключові фольклорні символи еротичного змісту стають у пісні джерелом комізму.

У світі існує безліч речей, які в людській свідомості впорядковуються й структуруються, а отже набувають номінативності. Але варто наголосити, що символічне й реальне $\epsilon$ не двома різними видами мови, а іiі різними точками бачення, кожна $з$ яких завжди в активі іншої. Так само і художній світ народної ліричної пісні в своїй творчій функції може в різноманітний спосіб бути або аналогічним до реального світу, або спілкуванням із слухачем у категоріях символічних через довільні зв'язки, наближення, асоціації, імпровізації, або зображенням людини як частини «природи». Проте немає причин, щоб якісь із можливих способів інтерпретації вважати упривілейованим. Тому еротичний текст пісень про кохання може бути витлумачений під двома оглядами: як частина якогось еротичного континууму, існуючого в межах цілісної системи фольклору, або у співвідношенні 3 іншими текстами цього жанрового різновиду, позбавленими елементів еротики. Отже, у першому випадку ми маємо справу з еротичним фольклором як цілісною системою, а твори усної лірики - це багатоваріантний вияв одного шару художньої реальності, то в другому випадку пісні, які розвивають еротичну тему, стають певною мірою самостійними, інтегруючись за естетичними, соціально-психологічними, ритуально-магічними функціями. І в цьому місці, власне, починаються запитання, які готовий поставити дослідник поетики фольклорної поезії, а саме: які джерела пісенних образів еротичного змісту? Яким способом у пісні кохання вводяться загальнофольклорні сексуалізовані мотиви й образи? Яку функцію вони виконують у новому тексті? Що вносять до загального змісту пісенних творів? Який же характер творчих позицій інтимної лірики? Проте, щоб відповісти на усі ці питання, треба перш за все глибше з'ясувати витоки семантики константних мотивів і символіки ліричних пісень про кохання.

Вивчення пам'яток усної культури давно вже показало, що фольклорна символіка має чималу сталість. Ця повторюваність, з одного боку спирається на властиві людині закони асоціативного мислення, при цьому поетична уява найчастіше відштовхується від зорової, а 3 другого - на спільні коди національної культури. I хоча художня практика XX-XXI ст. зробила символ широкосяжним поняттям (це мова, міф, релігія, мистецтво, наука), за допомогою якого людина упорядковує навколишній хаос (Е. Кассірер), чи ототожнює символ з психо- 
патологічним симптомом (3. Фройд), чи відгадує все багатство символіки людства як окреслення стабільних фігур підсвідомого (К. Юнг), проте цим вона увиразнила раціональні та позараціональні аспекти символу. Так само й у піснях про кохання еротичні символи постають як базова опозиція чоловічий/љіночий, міць і вирішальну силу якої як головної полярності в культурній моделі світу справедливо пов'язують 3 активною, творчою взаємодією опозитів, котрі й є суттю творіння, гарантом існування світу, воднораз як і одним із основних параметрів стереотипу поведінки людини. Прикметний, окрім того, поділ обрядових культів і вербальних текстів, що їх супроводжують і коментують, на чоловічі та жіночі. Тому цілком закономірною в піснях про кохання $€$ класифікація елементів еротичного континууму за ознакою чоловіче/жіноче, під яку систематизуються і не то що предмети, явища, дії, особливо пов'язані з сексуальним універсумом, а й різні - від архаїчних до сучасних сюжети і традиції. Навіть символи еротичного характеру фольклористи найчастіше поділяють на дві групи - чоловічі та жіночі, як поділяє, наприклад, символи сновидінь 3. Фройд. Тож словесні елементи (вогонь, блискав$\kappa a$, дуб, півень, кінь, хліб, ніж) перетворювалися в пісні на фігури поетичної мови й несли у собі чоловічий символ. А вода, земля, береза, курка, риба, корова, двері, ворота, піч, посудина, скринька, кімната - жіночі. Втім, пісні кохання поєднують переважно обидва елементи.

Однак, як тілесна тема чи еротичні картини у фольклорі ніколи не розкриваються, не відображуються з подробицями, так власне сексуальна практика рідко стає ключовою темою творів усної лірики й зазвичай підлягає табуюванню та перекодуванню насамперед мовою космогонії. Основний спосіб інтерпретації сексуальноорієнтованих мотивів у фольклорі й як на тепер полягає в тому, як вони розумілися в категоріях аграрної магії чи в якомусь реконструйованому інституті первісної спільноти: прокреація, відновлення життя співвідносилося 3 космогонічним процесом, 3 певними міфопоетичними ідеями (поєднання жіночої відтворювальної сили й чоловічого первня як джерело життя, усвідомлення землі як жіночого організму, сприйняття архаїчного мотиву природного єднання з землею як шлюбних стосунків між небом і землею, що дає початок життю). Це означає, передусім, що хоча сексуальність приявна в піснях про кохання як цілком визначене і самодостатне явище в усьому розмаїтті виявів, іiі треба намагатися сприймати такою, якою сприймає іiї сам носій фольклору - тобто в іiі первісному значенні. Дійсно, сюжети більшості любовних пісень побудовані на тілесному підгрунті, адже в усіх них $є$ висловлювання еротичних почувань і жаги, фігурують незмінні мотиви парування, шлюбу й шлюбних стосунків, продовження роду. Проте, говорячи про еротичний підтекст, не можна обминути факт, що різноманітні сенси, приписувані цьому явищу, сполучаються у творах із зображенням різних почуттів чи емоцій людини, всіляких життєвих ситуацій, розпізнати суть яких можна то реалістично, то символічно. Щоб зрозуміти цю закономірність, ми повинні зауважити, що, наприклад, їжі, напоям у традиційних культурах різних народів світу приписуються виразні еротичні конотації, з одного боку, з іншого - сфера їхнього функціонування знаходиться водночас і в побутовому ареалі діяльності людини, але поширюється i на ділянку ритуально- міфологічних уявлень.

Тому наступний важливий приклад еротичної символіки усної лірики - секс та їжа. Адже, як відомо, секс сприймається міфологічною свідомістю як діяльність медіативного плану, поїдання й статева злука - явища одного порядку, а зажиття їжі в архаїчній свідомості поєднується $з$ моментами народження, шлюбу та смерті. Уявлення ці виявились надзвичайно стійкими в традиційній культурі. Останнє особливо важливе, оскільки лірична пісенність включає мотивні та образні ресурси творів різних жанрів народної словесності, об'єднаних сексуально-еротичною тематикою, ігровим характером, символічними фігурами, а динамічною моделлю інтеграції багатоманітних явищ традиційної культури $\epsilon$, без сумніву, ритуальна практика - календарна обрядовість і поезія та весільна драма. Доказом того, що секс та їжа в піснях про кохання - це ідеальна модель символічної картини світу, є мотиви поїдання, ковтання, пиття, запрошення на обід і спільна трапеза, напування коня (пісні «Треба, мати, рано встати», «Де ти ся, мій миленький, забавив, забавив», «Ох, та не люби двох» та ін.).

Ми зазвичай у поспіху розглядаємо деякі абстрактні уявлення як просто реалії життя чи тільки поетичні метафори - тоді їхня архаїчна семантика стає непевною й невиразною. А от народи Півночі та Сибіру з їхною самобутньо-архаїчною релігійною свідомістю зберегли примітивну здатність прямої персоніфікації уявлень. Про еротичну символіку спільного зажиття їжі та співвіднесеність його з «милуванням» можна робити висновок на підставі хантийського, мансійського етнографічного матеріалу. Так, у мансі статевий акт називається «mай хатей» - «один одного їдять», а аналогія, звичайно, в тому, що обидва акти спрямовані на продовження життя, й як з'їдена страва стає частиною самої людини, так і в статевому акті жінка стає частиною чоловіка. Тому більшої, ніж метафоричний зміст, уваги вимагають поняття в традиційній пісні про кохання, які стосуються їсва, питва. У пісенному тексті вони виступають не як найменування предмета чи дії, а як одиниця міфологічної картини світу. Таким узагалі $є$ значення широко відомого образу їжі - хліба і питва (вина, води) - як архаїного осмислення дійства, котре бере свої початки ще у тотемізмі. Він зберігся в різних формах духовної культури людства: від релігійного обряду до традиційної метафори у фольклорі та літературі. Дійство поїдання одночасно пов'язане і з ритуалом жертвоприношення, і 3 образами народження, парування, смерті й воскресіння, а як метафора збереглося до найновіших часів, звичайно, втративши своє архаїчне значення, продукуючи нове осмислення і часом дуже несхожу семантику. Про деякі 3 них - у виразній еротичній конотації - ми вже згадували.

Натомість варто зазначити роль їжі - ритуальної трапези - як одного з ключових компонентів звичаїв та обрядів родинного та календарного циклів. Окремим видам ритуальних страв, завдяки їхньої ролі в магічних діях, надавались завжди надприродні якості (сила родючості, цілюща, апотропеїчна), і вони сприймались уже не як звичайна їжа, а лише як оберег або пожертва. Природно, з часом магічна значущість їжі отримала й інші тлумачення або збереглася як традиція, інколи незрозуміла й для самих учасників трапези. Але у різноманітних маніфестаціях еротики в їжі, напоях, спільній трапезі 
(прямих або символічних), пов'язаних із календарними обрядами чи родинною обрядовістю, відзначається відсутність будь-якого зв'язку з господарською діяльністю. Ці символи несуть свою мету в собі самих, в яких еротика не служить якимось іншим задачам, не залежить ні від чого, передаючи різні форми й відтінки інтимних стосунків. Однак одним із постійних метафоричних значень дійства зажиття їжі у традиційній культурі слов'ян залишається його значення «ваблення», «почуттєвого кохання», «парування». Це дійство по-різному, але постійно, обіграється в обрядовій поезії, ліричних піснях та в інших жанрах народнопоетичної творчості. Адже у фольклорі зображення шлюбного комплексу, первісного шлюбу не в побутовому чи релігійному, а в космогонічному значенні - мета символізації, головне, що передається символом. Усі ці форми дуже розвинені в піснях про кохання. Очевидно, символічні функції їжі - передусім в обрядах - оформлюються в метафору «любов їжа», яка дала постійні й різноманітні семантичні паралелі, аналогії в народній пісні: запрошення коханого на обід, спільний обід, годування, приготування «принадоньки», приворот-зілля. У цих елементарних сюжетах поетичне мотивування, звичайно, покликане дещо замаскувати відкриті почуття закоханих. 3 мотивом їсти любити та його пісенними варіантами співвідносяться елементи та ритуальні дії весільного обряду, в якому обрядові страви і трапеза виконують центральну роль, а окремі епізоди та атрибути обряду виступають як персоніфікації дійства їжі та головних учасників обряду. Однак у системі художніх образів пісень про кохання дійство зажиття їжі, атрибути обіду (хліб, зерно, риба, вода, напої), приготування їжі (варіння) нерідко усвідомлюються цілком реалістично й не несуть у собі того обсценного значення, яке лежить у понятті «їсти» - любити, «пиття» - любов і переважає у весільних сороміцьких текстах, що виконувалися під час перезви і «комори».

А втім варто знову повернутися до константних мотивів пісень про кохання: «напування», «пиття». Семантиці цих мотивів приписується ще й універсальна властивість статевої енергії. Тут засадничим принципом $\epsilon$ те, що рідина - від поняття «вода життя» до фізіологічних речовин (сімені, молока, крові, слини) - означає життя, тоді як втрата рідини означає смерть. Поетичне розкодування семантики цих мотивів у піснях кохання традиційно йшло від семантики й структури весільного обряду, а передусім - від шлюбних мотивів весільних пісень, від давніх уявлень про продовження роду, родючість, про міжстатеві та міжродові стосунки давніх шлюбних інституцій. Одначе, як в описі весільного обряду інформація, наприклад, про першу шлюбну ніч мізерна, певно, 3 огляду на сакральність інформації, яка не належна оприлюдненню поза обрядом (хоча тут і наводиться безліч етнографічних подробиць: дії, одяг, їжа, весільні чини), так і пісні весільні - скупі на слова з відвертим еротичним змістом, дефіцит яких здатні були поповнити обрядодії. Тим часом у любовних піснях фольклорні сексуалізовані символи постають не як пригадка про весільний обряд, не від поетичної фантазії чи просто на основі асоціативного мислення. Вони навіть виходять за межі художнього образу. Це сфера не інтуїтивних здогадок, які можна перевірити реальними спостереженнями - для необізнаних з народною культурою вони залишаться незрозумілими. Проте, якщо спробувати поясни- ти цю ситуацію з іншого боку, можна було б сказати: те, що для некомпетентних непоясниме - доступне і ясне для носія цієї культури. Тут ми маємо певність, що про зміст таких сексуалізованих мотивів, як «напування коня», «просьба парубка дати йому напитися», «спільний обід i частування парубка», «запрошення парубка на обід (вечерю)», «очікування спільного обіду», «годування, приготування «принадоньки» і приворотного зілля для коханого», які в українських народних піснях стобарвно і майстерно розкривають тему зближення, парування, пошлюблення і прокреації, суб'єктам культурного соціуму не треба говорити. Це домінатні теми багатьох класичних пісень про кохання, наприклад, у запиcax Зоріана Доленги-Ходаковського, Михайла Павлика, Осипа та Федора Бодянських («Ой де тая вдова живе, що на рожку хата», «Ой 3-за гори чорна хмара, з-за гори», «Ой дівчина по гриби ходила», «Ой відти гора, відти другая», «І по той бік гора, і по сей бік гора», «Ой через сад зелененький», «Ой у полі верба, холодная вода», «Треба, мати, рано встати», «Цвіте мачок невеличок, нема цвіту зміни», «Ой під вишнею, під черешнею», «В неділю раненько, іще невиденько»).

Щоб точніше прояснити поетику народних пісень еротичного змісту, маємо пригадати: кожна модель культури містить у собі поділ явищ навколишньої дійсності на світ фактів і світ знаків. Хоча, безперечно, цей поділ і не абсолютний. А відбувається так тому, що, з правила, будь-яка річ має не одну функцію, а цілий набір, серед яких є і практичні, $є$ і символічні. Проте семіотичний статус предмета в традиційній культурі може суттєво змінюватись у часі, носити різне значення залежно від ситуації. У цьому плані акти спільного спожиття їжі й пиття, опис технологічних процесів, ритуалізованих дій, які як фрагменти входили в єдину систему первісного синкретизму, в піснях кохання особливо цікаві. Скажімо, в пісні «Ой сон, мати, ой сон, мати» нероздільний характер первісних уявлень, тотожність слова, предмета й дії, що мають спільну семантику, в акті спільного спожиття їжі й пиття виявляється на рівні зв'язків з вербальними і позавербальними компонентами обряду:

Приїхали до дівчини три козаченьки пізно.

Наварила їм дівчина да вечеряти різно:

Ой першому вечеронька - да варенички в маслі,

А другому вечеронька - да шавлія та рута,

А третьому вечеронька - сама щира отрута.

А в іншій пісні («Ой журавель та у гуслі гра») - 3 різними формами ритуалізованих дій, видами обміну (обмін дарами, спільна трапеза тощо):

$$
\begin{gathered}
\text { Дівчина голосить } \\
\text { Вона свого козаченька } \\
\text { Вечеряти просить: } \\
\text { «рийди, прийди, козаченьку, } \\
\text { До мене вечеряти; } \\
\text { Як не прийдеш вечеряти - } \\
\text { Прийди обідати; } \\
\text { Як не прийдеш обідати - } \\
\text { Прийди поснідати; } \\
\text { Як не прийдеш поснідати - } \\
\text { Прийди одвідати». }
\end{gathered}
$$

Проте широкий ареал побутування ритуального обіду у східних слов'ян та утворення на основі обрядових форм фольклорних уявлень про еротико-прокреативну символіку їжі, плодів, хліба, зерна, води, напоїв говорить 
не про запозичення піснею відповідних обрядів вже тому, що пісня не асимілювалася повністю з обрядом, а обрядові символи тільки використовуються в ній з позаобрядовою метою. Критерієм оцінки структуральнотипологічних зіставлень архаїчних матеріалів, пов'язаних $з$ ритуальними функціями води й подібними фольклорними мотивами, незважаючи на їх полісемантичність, завуальованість чи відвертість семантики, є не «конкретизація» цих архетипних образів, закорінених у колективному підсвідомому, а естетична та комунікативна функціональність в еротичному підтексті пісні.

Зрозуміло, дистанція між метафоричними архетипами та художніми образами пісень про кохання настільки значна, що для свідомості сучасного реципієнта ці архетипи відчутно затемнилися і практично не сприймаються у своєму первісному значенні. Лише описавши їхню структуру і трансформовану історію, реконструювавши найпростіші образні ядра, можна віднайти їх схожість. Ці змісти художнього світу пісень кохання можна оцінювати насамперед 3 позицій магічних ритуальних дій, віри в магічну силу природи, речей, слова як протидії злу й оберігання від зла, знешкодження ворога, як поліпшення життя, приворожування хлопців або віднадження нелюба. Так, традиційні пісенні формули «запрошення на обід», «готування дівчиною «принадоньки» $\epsilon$ інтерпретуючими моделями ритуалу ворожінь типу «годування - задобрювання» із циклу гіластичних, тобто умилостивлюючих обрядів, спрямованих на уласкавлення духів-опікунів. Як відомо, до жертвоприношення нерідко зверталися з метою ворожіння. Різні варіанти ворожінь (використання обрядової їжі - куті, накривання столу на двох, розстеляння на землі рушника, «посівання» зерна, насіння коноплі, льону біля колодязя, в хаті, біля печі та ін.) зводяться до головного: закликаючи до столу, на вечерю Долю чи інших міфологічних персонажів, святих (Андрія, Василя), а найчастіше духа, котрого дівчина називала «судженим», вона ворожила на майбутнє, на нареченого, якого очікує на вечерю. Усі ці ворожіння пов'язані з проріканням заміжжя, весілля, долі дівчини і мають еротичний підтекст у широкому розумінні. Тут іще треба додати: ритуал засівання та всі символічні асоціації в семіотичному просторі традиційних землеробських культур розцінюється як запліднення Землі-матері й тому водночас сприймається як ефективний магічний засіб завороження шлюбу. 3 усього видно, що всі ці мотиви (їжа - жертвоприношення - дар) - поліфункціональні.

Скажімо, в пісні «Котилася та зоря з неба» мотив готування дівчиною «принадоньки» знаходить свою паралель у одному з різновидів дівочих ворожінь - годування собаки, курки, півня. Принаймні такий висновок можна зробити 3 етнографічних записів М. Маркевича: «Дівчата насипали кожна купку зерна, впускали півня i примічали, чию купку він клюне раніше інших, та й вийде заміж. Або садовили півня в діжу і ставили на покутті, на підлозі ставили миску з водою й насипали поруч купки проса, жита, гречки. Якщо півень із діжі кинеться на зерно - наречений буде добрим хазяїном, якщо він кинеться до води - наречений буде поганим, п'яницею» [5, с. 66]. I тут варто придивитися до цих фольклорних формул не лише з боку констатації зв'язків пісні з іншими народнопоетичними чи етнографічними текстами, а й в плані вираження нехудожньої дійсності - ритуально-магічної практики. Такою дійсністю (точніше сказати, іï поетичною альтернативою) в поетиці ліричних пісень $\epsilon$ особливе ставлення до формул побажання, $\mathrm{i}$ навіть жартівливе, ігрове їх використання, що, одначе, не перетворює їх у пісні на прості слова. Якщо, наприклад, для сакральної лексики ритуальних образів (хлібсіль), ритуальних дій (трапеза) особливо характерне небуденне ставлення до слова-знака, дії-знака, бо саме в сфері сакрального найбільшою мірою відбувається табуювання понять і висловів, то саме через це прокльони й ті в ліричній пісні з'єднуються 3 лексикою сакральною (Коли ж мене покидаєш, покинь хліба їсти,|| Бодай тобі Господь не дав із іншою сісти). До ототожнення ритуально-магічної дійсності та художньої лірична пісня залучає загальнофольклорні формули-побажання, формули-величання, формули-прокльони, молитовні форми, котрі, вважає М.Грушевський, є «тільки нюанси одної магічної гадки» [3, с. 137]. Дійсно, як в основі величань в обрядовій поезії закладена віра й упевненість людини у всемогутню силу слова, так і побажання в піснях позаобрядових (хоча вони лише ілюзія реальних висловлювань), по суті, не тільки демонструють почуття та бажання ліричного героя, а й нафантазоване ним урегулювання стосунків 3 партнером.

Момент віднесення призивання до метафори, в якій усяке слово тотожне дії, усяке іменування $є$ відтворенням дійства, присутній в обрядах інвокацій (називання за ім'ям, викликання, апеляція до природних стихій), гімнах, котрі послуговуються формулами призивання до жертовної їжі, став одним із головних чинників ритуально-магічної функції в голосіннях, обрядових віншуваннях. Найбільш стійкі поетичні формули величання й побажання обрядового фольклору вийшли за жанрові межі, перейшли до позаобрядових пісенних жанрів, втративши своє магічно-ритуальне значення і посиливши в народній ліричній пісні чуттєві, любовні мотиви. Якщо ми інтерпретуємо пісенні мотиви (наприклад, «запрошення парубка на обід», «частування») як моделювання мікрокосму людини, то через те, що за всієї відмінності від ритуальної формули призивання вони в новому тексті зберігають свій архаїчний зміст, значення якого виходить далеко за межі реально-побутового. Саме тому згадані пісенні мотиви $\epsilon$ не просто ланкою в сюжетному ланцюжку основних подій пісні, а визначаються безпосереднім відношенням до моделі світу. А різні варіанти цієї формули - це різноманітні засоби трансляції різних семантичних, етичних значень, емоційного стану людини. Отже, можна сказати, що семантика архаїчної формули призивання в любовній ліриці більше проектує дійсність, моделює поведінку і бажання людини стосовно актуальної дійсності, ніж відображає ії поверхневий реально-побутовий рівень, у контексті пісні змінює свій просторовий регістр, а неусвідомлюване архетипне значення «парування» відкриває психологію та вчинки ліричного героя. Ясна річ, що магічна сила запрошення до спільного обіду подвоювалась, коли в ній використовувалась смілива еротична асоціація, як в пісні «Прилетів соловей, сів на печи»:

Прилетів соловей, сів на печи, Дають єму їстоньки все калачи, Дают єму питоньки все горілки, Час тобі, Івасьо, до дівки.

Висновки. Як бачимо, у формульних мотивах любо- 
вної пісні помічаються ті форми символічної діяльності (магія, жертвоприношення, обдаровування), в яких через ряд символічних дій у вигляді знаків використовуються не тільки словесний матеріал, а й речі, стан, зображення або вчинки людини, іiі почуття. Вони, набираючи значення мнемонічних символів, складають фонд колективної пам'яті і не випадково, а під дією механізмів свідомого вибору, моделюють у структурі пісні аналогічний акт комунікації та бажаний результат. Саме діалогічна природа подібних ритуально-магічних акцій обумовлює й основні особливості їхньої внутрішньої організації як «текстів», передача й отримання яких покликані забезпечити досягнення певної мети, емоційного комфорту. Давно вже доведено, що впливова сила традиційної пісні кохання завжди корінилася в простих, виразних, викінчених, відібраних багатовіковим досвідом народу засобах, якими він оперує: психологічний паралелізм, символіка, метафора, образи-аналогії та словесні співзвуччя, постійні епітети, тавтологія, гіпербола та літота, різноманітні повтори та асоціації, зменшувальна лексика, досконала, багата й невимушена ритміка та мовноакустична організація пісенного тексту. При цьому важливо підкреслити, що народна пісня про кохання загалом дуже лаконічна, використовує тропи з функціональною метою, найголовнішою $з$ яких $є$ акцентування певного важливого компонента загального ліричного малюнка, досягнення незрівнянної виразності й граціозності вислову інтимних почуттів.

\section{ЛІТЕРАТУРА}

1. Бернштам Т.А. Молодежь в обрядовой жизни русской общины XIX - начала XX в. Половозрастной аспект традиционной культуры. - Л.: Наука, 1988. - 280 с.; Успенский Б.А. Мифологический аспект русской экспрессивной фразеологии // Успенский Б.А. Избранные труды. В 2-х томах. - М.: Гнозис, 1994. - Т.

2. Виноградова Л.Н. Фольлор как источник для реконструкции древней славянской духовной культуры // Славянский и балканский фольклор: Реконструкция древней культуры: Источники и методы. - М.: «Наука», 1989. - С. 101-121.

3. Грушевський М. Молитви і закляття // М. Грушевський. Icторія української літератури. У 6-ти т., 9-ти кн. - К.: Либідь, 1993. - T.1. - C.137- 145 .

4. Леви-Стросс К. Структурная антропология. - М.: «Наука», 1985. $-536 \mathrm{c}$.

5. Маркевич Н. Обычаи, поверья, кухня и напитки малороссиян

// Українці: народні вірування повір'я, демонологія: 2-е вид./ Упор., прим. та біограф. нариси А.П. Пономарьова, Т.В. Косміної, О.О. Боряк. - К.: Либідь, 1992. - С. 52-169.

6. Рецензія В. Гнатюка на публікацію еротичної поезії Х. Вовком // Записки Наукового товариства імені Шевченка/впорядкував М. Грушевський. - Львів : Друк. Наук. т-ва ім. Шевченка, 1990. - Т.33. - Кн. 5. - [200] с.

7. Топоров В.Н. О ритуале. Введение в проблематику // Архаический ритуал в фольклорных и раннелитератрных памятниках. - М.: Главная редакция восточной литературы издательства «Наука», 1988. - С.7-60.

8. Фрейд 3. Психология бессознательного. Сб. произведений/Сост., науч. ред., авт. вступ. ст. М.Г. Ярошевский. - М.: Просвещение, 1990. - 448 с.

\section{REFERENCES}

1. Bernshtam T.A. Youth in the ritual life of the Russian community of the XIX - beginning of the XX century. Sexual age aspect of traditional culture. - L.: «Nauka», $1988-280$ p; Uspenskiy B.A. The mythological aspect of Russian expressive phraseology // Uspenskiy B.A. Selected works. In 2 volumes.- M.: Gnozis, 1994. T.

2. Vinogradova L.N. Folklore as a source for the reconstruction of the ancient Slavic spiritual culture // Slavic and Balkan Folklore: Reconstruction of Ancient Culture: Sources and Methods. - M.: «Nauka», 1989. - P. 101-121.

3. Grushevskiy M. Prayers and curses // M. Grushevskiy. History of Ukrainian Literature. In 6 volumes, 9 books. - K.: Libid, 1993. V.1. - P.137-145.

4. Levi-Stross K. Structural Anthropology. - M., 1985. - 536 p.

5. Markevich N. The customs, beliefs, cuisine and drinks of the

Russians // Ukrainians: People's Beliefs of Belief, Demonology: 2nd Edition/Cf. and biographer. Essays A.P. Ponomarova, T.V. Kosminoyi, O.O. Boryak. - K.: Libid, 1992. - P. 52-169.

6. V. Hnatyuk's Review on the Publication of Erotic Poetry by $\mathrm{H}$. Vovk // Notes by Shevchenko Scientific Society/edited by M. Hrushevsky. - Lviv: Print. Science. t-in it. Shevchenko, 1990. Vol. 33. - Book. 5. - [200] p.

7. Toporov V.N. About the ritual. Introduction to the Problems // Archaic Ritual in Folklore and Early Literature Monuments. M.: Glavnaya redaktsiya vostochnoy literaturyi izdatelstva «Nauka», 1988. - P.7-60.

8. Freud, Z. Psychology of the Unconscious. works/Comp., scientific. ed., ed. entry Art. M.G. Yaroshevsky. M.:Prosveschenie, 1990.-- 448 p.

\section{Aesthetic communication function and «material» meaning of the word in folk text}

\section{Kopanytsya}

Abstract. The studio offers an interpretation of the aesthetic communication function of the erotic subtext of the folklore work as the inner meaning of the word, the cultural code in its metaphorical transformations, a certain kind of "language" of human communication, which generally contributes to the formation of song poetics. Criteria and methodological principles of studying the symbolism of lyric songs are formulated.

Keywords: lyric song, erotic subtext, symbol, poetic language, communication 